\title{
Arsenic Behaviour in Polluted Soils After Remediation Activities
}

\author{
Francisco Martín' ${ }^{1}$ Mariano Simón², Elena Arco ${ }^{1}$, \\ Ana Romero ${ }^{1}$ and Carlos Dorronsoro ${ }^{1}$ \\ ${ }^{1}$ Soil Science Department, Faculty of Science, \\ University of Granada, Campus Fuentenueva s/n, Granada, \\ ${ }^{2}$ Soil Science Department, EPS CITE IIB, \\ University of Almería, Carretera Sacramento s/ $n$, Almería
}

Spain

\section{Introduction}

Arsenic (As) in soil is a serious environmental problem due to its potential high toxicity. Under field conditions As can accumulate in contaminated soils because it is only partially removed by leaching, methylation, and erosion or because it is only slightly taken up and accumulated by plants. Chemically, As exists as organic and inorganic species. It has two main oxidation states $(+\mathrm{III}$ and $+\mathrm{V})$, depending on the type and amounts of sorbents, $\mathrm{pH}$, redox potential (Eh), and microbial activity (Yong \& Mulligan, 2004). Inorganic compounds are the most frequent in soil due to their water solubility. The most thermodynamically stable species within the $\mathrm{pH}$ range 4.0-8.0 include $\mathrm{H}_{3} \mathrm{AsO}_{3}$ of $\mathrm{As}^{\mathrm{IIII}}$, and $\mathrm{HAsO}_{4}{ }^{2-}$ and $\mathrm{H}_{2} \mathrm{AsO}_{4}{ }^{-}$ of $\mathrm{As}^{\mathrm{v}}$ (Smith et al., 1998). Asv species predominate in soil solutions under moderate reducing conditions, but AsIII forms are more abundant when the redox potential is below $500 \mathrm{mV}$, according to Masscheleyn et al. (1991). These authors also indicate that a rise in $\mathrm{pH}$, or a fall in Asv to AsIII, boost the concentration of As in the solution, while its solubility under moderately reducing conditions is controlled by the dissolution of iron hydroxides (Marin et al. 1993). On the other hand, it is well known that the As concentration in a soil solution is governed by the physical and chemical properties of the soil, which influence adsorption-desorption processes. Arsenic has a high affinity for oxidic surfaces, and the reactivity of the oxides varies considerably with the $\mathrm{pH}$, the charge density, and the composition of the soil solution. The soil texture and the nature of the mineral constituents also affect adsorption processes (Hiltbold, 1974). Pierce and Moore (1980) demonstrated the specificity of the surface of iron hydroxides and the influence of $\mathrm{pH}$ in As adsorption.

In soils, As has low mobility and under reducing conditions the concentration of dissolved As in soil solution declines. The availability of this element in soils can increase under acidic conditions (mainly pH below 5), due to the greater solubility of the iron and aluminium compounds, which augment As toxicity ( $\left.\mathrm{O}^{\prime} \mathrm{Neill}, 1995\right)$. In general, the mobility of this element is directly related to the total amount of As and inversely to time as well as to the iron and aluminium content; also, under oxidation conditions, its bioavailability is strongly limited (Kabata-Pendias \& Pendias, 2001). 
Compared to the abundant data on As adsorption, little information is available on As desorption in soils. In this sense, Carbonell et al. (1996) discovered that the adsorption of As ${ }^{I I I}$ forms is a reversible process, whereas the adsorption of $\mathrm{As}^{\mathrm{v}}$ is a hysteresial process. Arsenic in soil is usually found in association with iron, aluminium, and manganese hydroxides, clays, and mineral oxyanions (sulphates, phosphates, and carbonates), which may serve as significant repositories of As due to their ubiquity in the environment (Foster, 2003). Iron hydroxides, such as goethite and ferrihydrite, are commonly found in soil and have been shown to be important in influencing the mobility behaviour of As (Foster, 2003; Jiang et al., 2005; Sun \& Doner, 1996; Waychunas et al., 1993). Arsenic behaviour in soil is related to many factors. Microbial activity changes the oxidation state, and the formation of volatile As compounds by methylation leads to losses of this element in the superficial horizons (Dudas, 1987). In any case, these reactions depend both on the microorganism type as well as on the As compound (NRCC, 1978). The presence of organic matter has been studied as a key factor in the desorption of arsenic from iron oxides, in this way, Redman et al. (2002) found that the interaction between natural organic matter and hematite diminished the sorption of arsenate, promoting its mobility, and other authors considered that dissolved organic matter can mobilize arsenic from iron oxides, increasing the concentration of this element in the solution (Bauer \& Blodau, 2006; Dobran \& Zagury, 2006; Mladenov et al., 2010). Otherwise, significant desorption of As is observed with the rise in $\mathrm{pH}$, in this case, the higher $\mathrm{pH}$ is related to the lower positive surface charge of the iron oxides, which facilitates the desorption of arsenate (Ghosh et al., 2006; Klitzke \& Lang, 2009; Masscheleyn et al., 1991).

In this chapter, we present a general overview of the current stage of As content in the soils after one of the most important accidents involving soil pollution in Spain in recent decades: the Aznalcollar mine spill (Seville, SW Spain) in 1998. In this accident, the settling pond of the pyrite mine in Aznalcóllar broke open, spilling some $3.6 \times 10^{6} \mathrm{~m}^{3}$ of water and $0.9 \times 10^{6}$ $\mathrm{m}^{3}$ of toxic tailings into the Agrio and Guadiamar river basins (Aguilar et al., 2003; Simón et al., 1998). The toxic tailings spread approximately $40 \mathrm{~km}$ downstream, reaching the wetlands of the Doñana National Park (proclaimed world heritage by UNESCO in 1994). The total affected area was roughly $55 \mathrm{~km}^{2}$. The disaster left sludge deposits between $1 \mathrm{~cm}$ to $1.5 \mathrm{~m}$ thick in different parts of the affected area (Simón et al., 1999; Lopez-Pamo et al., 1999). Arsenic was one of the major components of the toxic tailings, with a mean concentration of $4953 \mathrm{mg} \mathrm{kg}^{-1}$ (López-Pamo et al., 1999). The correlation between total As and sulphur strongly suggest that As was present in the tailings as arsenopyrite (FeAsS) and that the oxidation of the tailings would release iron and As (Simón et al., 2001). The remediation of soils was focused on the clean-up of the tailings and uppermost layer of the heavily polluted soils, together with the application of blocking agents to neutralize the acidity and to immobilize the highly soluble As concentrations (Aguilar et al., 2007b). Cleanup operations began almost immediately, so that by November 1998 the tailings were almost completely removed with heavy machinery and the acidic waters had been treated and discharged (Aguilar et al., 2003). To neutralize the acidity, liming material (sugarrefinery scum) was applied throughout the affected area at rates ranging from 20 to $150 \mathrm{Tm}$ ha $^{-1}$. For arsenic immobilization, red soils rich in iron and located next to the affected area (Mudarra, 1988) were used; these soils had a concentration in free-iron oxides of between $2.26 \%$ and $6.31 \%$, and the application rate ranged between 120 and $300 \mathrm{Tm}^{\mathrm{T}} \mathrm{a}^{-1}$. Due to the climatic conditions (Mediterranean climate with ETP > precipitation), the soil solution tended to move upwards and concentrate the pollutants at the soil surface (Simón et al., 
2007). In the case of moderately polluted areas, when the aforementioned remediation actions were not feasible, the soils were tilled and homogenized to a depth of $25 \mathrm{~cm}$, causing the As concentrations to decline in these soils to below the intervention level, although this action did not reduce the pollution.

Phytoremediation was also applied in some parts of the affected area (Clemente et al., 2006; Peñalosa et al., 2007), but the results at the plot scale were not effective enough to apply for the recovery of the whole area (Clemente et al., 2005; Madejón et al., 2003; Pérez de Mora et al., 2006). The final measurement was the stabilization of the soils by revegetation with native plants. A monitoring of the area in 2004 (6 years after the accident) revealed that although the remediation measurements lowered the As concentrations, the percentage of soils exceeding the maximum permitted level for agricultural soils was around $65 \%$ of the total affected soils, while around $30 \%$ of the soils had even doubled the maximum permitted of As (100 mg kg-1; Simón et al., 2009).

In this chapter, we present a general overview of the time course of As content in soils during the remediation actions undertaken in the affected area. We present monitoring data 12 years after the accident and discuss the implications of the remediation measurements in relation to the mobility of As in soils over time.

\section{Material and methods}

To assess the arsenic contamination level in the basin, we made a systematic sampling in the affected area after the removal of the tailings covering the soils, using a network $(400 \mathrm{x}$ $400 \mathrm{~m}$ ) and randomly selecting 100 sampling points. At each sampling point, samples were taken at the centre and four corners of a square (10 m side), at $0-10,10-30$, and $30-50 \mathrm{~cm}$ in depth. The samples for the same depth were mixed and homogenized, providing 3 samples per sampling point. Samples were also collected from uncontaminated soils in nearby areas unaffected by the spill.

After the study of the main soil properties between 0 and $50 \mathrm{~cm}$ in depth, samples were grouped into five different types using a cluster analysis via the k-mean method (Figure 1). Soil types 1 and 2 (no-carbonate sector), located in the upper part of the basin, closest to the tailing pond, were slightly acidic; type 1 had a loamy texture while type 2 was dominated by sand and gravel. Soil types 3,4, and 5 (carbonate sector) were predominantly neutral or slightly alkaline, the main differences between them being texture (type 3, clay loam; type 4, loam; type 5, silty clay). The soils in the affected area were classified as Typic Xerofluvent (upper part of the basin) and Typic Xerorthent (middle and lower part of the basin) (Soil Survey Staff, 2003). Field descriptions of soils were based on procedures of the Soil Survey Staff (1951).

Soil samples were air-dried and sieved to $2 \mathrm{~mm}$ to estimate the gravel content. Soil analyses were made with the $<2 \mathrm{~mm}$ fraction. Sulphate was determined in the saturation extract (water-soluble sulphate) by ion chromatography in a Dionex-120 chromatograph. Particlesize distribution was determined by the pipette method after the elimination of organic matter with $\mathrm{H}_{2} \mathrm{O}_{2}$ and dispersion with sodium hexametaphosphate (Loveland \& Whalley, 1991). The $\mathrm{pH}$ was measured potentiometrically in a 1:2.5 soil:water suspension. The $\mathrm{CaCO}_{3}$ equivalent was determined by the method of Bascomb (1961). Total carbon was analysed by dry combustion with a LECO SC-144DR instrument. Organic carbon (OC) was determined by the difference between total carbon and inorganic carbon from $\mathrm{CaCO}_{3}$. The cation-exchange capacity (CEC) was determined with $1 \mathrm{~N}$ Na-acetate at $\mathrm{pH} 8.2$, measuring the sodium in a 
METEOR NAK-II flame-photometer. The total concentration of iron $\left(\mathrm{Fe}_{\mathrm{T}}\right)$ was measured by Xray fluorescence in a Philips PW-1404 instrument, from a disc of soil and lithium tetraborate in a ratio of 0.6:5.5. Poorly crystallized iron oxides $\left(\mathrm{Fe}_{\mathrm{O}}\right)$ were extracted with ammonium oxalate (Schwertmann \& Taylor, 1977), and measured by atomic absorption spectroscopy.
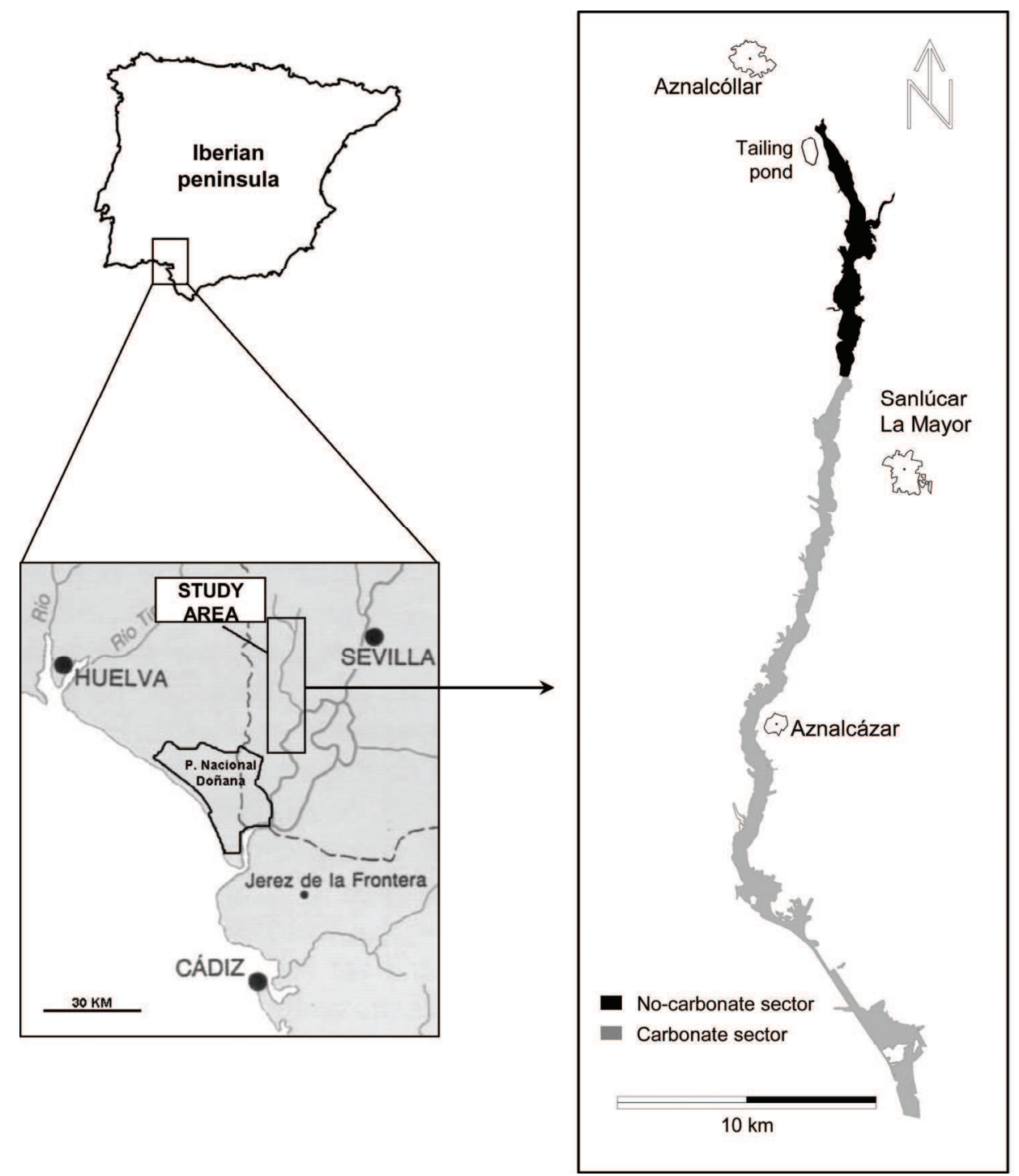

Fig. 1. Location of the area affected by the pyrite tailing spill

Soil samples were finely ground $(<0.05 \mathrm{~mm})$, and digested in strong acids $\left(\mathrm{HNO}_{3}+\mathrm{HF}\right)$; in these dissolutions, total As values were determined by ICP-MS in a Perkin Elmer Elan 5000 instrument. A Multi-element Calibration Standard 4 (Perkin-Elmer) was used with Rh as the 
internal standard. The detection limit for As in soils measured by this technique was $0.01 \mu \mathrm{g}$ ${ }^{1-1}$.The accuracy of the method was corroborated by analyses (six replicates) of a standard reference material: SRM 2711 (soil with moderately elevated trace-element concentrations). For As, the mean certified value was $105.0 \mathrm{mg} \mathrm{kg}^{-1}$ with a standard deviation of 8.0; the mean experimental value was $102.4 \mathrm{mg} \mathrm{kg}^{-1}$ with a standard deviation of 1.1. For the study of the mobility of As forms in soil samples, extractions were conducted with distilled water and EDTA (AsW and AsE, respectively; Quevauviller et al., 1998), and ammonium oxalate (AsO; Schwertmann \& Taylor, 1977).

Toxicity bioassays were made with the water extract (1:5 soil:water ratio) of the affected soils to assess the potential risk of the soil-water solution. We used two types of bioassays: i) the response of bioluminescent bacteria Vibrio fischeri according to Microtox Basic Test for Aqueous Extracts Protocol (AZUR Environmental, 1998); and ii) seed-germination text with lettuce (Lactuca sativa L.) according to the US EPA (1996) procedure.

\section{Results and discussion}

\subsection{Initial pollution (the year of the accident)}

The accident (25th April, 1998) caused a spill that covered the soils with variable amounts of tailings and polluted waters. The mean concentration of As in the tailings was $4953 \mathrm{mg} \mathrm{kg-1}$, and in the waters $0.002 \mathrm{mg} \mathrm{l}^{-1}$. According to Simón et al. (2007) the As contamination entered the soil mainly from the solid phase, and estimation of the quantity of tailings that penetrated the soil ranged from 1.7 to $150.8 \mathrm{mg}$ tailing per $\mathrm{kg}$ soil, depending on the affected sector considered. Nine days after the spill (May, 1998), with the soils still covered by the tailings, the mean As concentration in the uppermost $10 \mathrm{~cm}$ of the soils was $121.7 \mathrm{mg} \mathrm{kg}-1$, although the pollution was very heterogeneous, mainly due to the soil properties, essentially structure, which affected the penetration of the tailings into the soil (Simón et al., 1999).

A few weeks after the spill (June, 1998), as result of drying and aeration of the tailings, sulphides oxidized to sulphates (Nordstrom, 1982), the $\mathrm{pH}$ fell markedly due to the formation of sulphuric acid (Stumm \& Morgan, 1981) and the formerly insoluble pollutants partly solubilized. During the weeks following the spill, this oxidation became evident, the sulphates increased rapidly in the tailings solution, this being accompanied by a sharp fall in the soil $\mathrm{pH}$ (with $\mathrm{pH}$ values up to 2.5 in the most polluted areas). The concentration of soluble As, measured in a water extract of tailings, was also found to vary over time. In this way, most of this solubilization occurred between 25 and 40 days from the spill (increasing more than 5-fold the water-soluble arsenic in soil in relation to the previous period), when the oxidation and solubilization of the sulphides bonding to arsenic in the tailings were highest and a rainfall period occurred. At 88 days from the spill (July, 1998), the oxidative pollution was negligible (Simón et al., 2007). This oxidative pollution sharply increased the arsenic contamination in the soils over time in the surface samplings $(0-10 \mathrm{~cm})$ but without increasing the pollution in the samples at $10-30 \mathrm{~cm}$ in depth (Aguilar et al., 2007a).

After the initial contamination (direct input of tailings into the soils) and the secondary contamination (infiltration of pollutant solutions coming from the oxidation of the tailings), the soils were considered strongly polluted. Because of the potential environmental risk of pollution, the first remediation measure was to clean-up the affected area; in this action, the tailings and the upper part of the soils (between 20 and $50 \mathrm{~cm}$ mean) were removed. The systematic sampling in the affected area after the clean-up (November, 1998) indicated that, after this measure the mean arsenic concentration in the uppermost $10 \mathrm{~cm}$ of the soils was 
$157.3 \mathrm{mg} \mathrm{kg}^{-1}$ (with maximum values up to $1,226.8 \mathrm{mg} \mathrm{kg}^{-1}$ ). The soil pollution exceeded the permitted value for agricultural soils in Andalusia (50 mg kg-1; Aguilar et al., 1999) for $82 \%$ of the overall surface area affected by the tailings, $96 \%$ in the no-carbonate sector (soil types 1 and 2), and $76.8 \%$ in the carbonate sector (soil types 3, 4 and 5). Meanwhile, $53 \%$ of the affected soils surpassed the limit of $100 \mathrm{mg} \mathrm{kg}^{-1}$ maximum permitted for Natural Park in Andalusia (Aguilar et al., 1999).

\subsection{Evolution of the soil pollution after the remediation actions}

The rapid clean-up of the affected area (in eight months, $45 \mathrm{~km}^{2}$ were cleaned) resulted in a deficient remediation action, as part of the tailings remained mixed with the soil, appearing residual tailings heterogeneously distributed throughout all the affected area. According to the high concentrations of As in soils after the clean-up conducted in 1998, secondary remediation actions were applied in the area between 1999 and 2001. These actions consisted in: i) repeat cleanup of the most polluted areas; ii) amendment applications (liming, organic matter, soils rich in iron oxides); and iii) tilling of the uppermost $25-30 \mathrm{~cm}$ to dilute the As concentrations in the upper $10 \mathrm{~cm}$ of the moderately contaminated soils. Phytoremediation was also applied in some parts of the affected area (Clemente et al., 2006; Peñalosa et al., 2007), but the results at the plot scale were not effective enough to apply for the recovery of the whole area (Clemente et al., 2005; Madejón et al., 2003; Pérez de Mora et al., 2006). The final measurement conducted in the area was the stabilization of the soils by revegetation with native plants.

After the end of all the remediation actions, the monitoring of the pollution made 6 years later (summer 2004) revealed that the initial pollution was reduced, but the reduction of the area exceeding the As concentration of $50 \mathrm{mg} \mathrm{kg}^{-1}$ was negligible, and around $30 \%$ of the area continued to exceed the intervention level of $100 \mathrm{mg} \mathrm{kg}^{-1}$ (Figure 2).

In all cases, the As pollution concentrated in the uppermost $10 \mathrm{~cm}$ of the soils and decreased sharply in depth, without significantly affecting the subsoil or groundwater (Simón et al., 2001, 2002, 2009; Dorronsoro et al., 2002).

To study the As retention in the soil, we made extractions with selective reagents (water, calcium chloride, acetic acid, EDTA, oxalic-oxalate). Arsenic was extracted mainly with oxalic-oxalate both in the non-carbonate sector (30\% in relation to the total As) and in the carbonate sector $(20 \%$ in relation to the total As). Considering oxalic-oxalate to be the reagent which extracts specifically the elements adsorbed onto oxides, we conclude that As is strongly retained by the iron oxides of the soil (Martin, 2002). The correlation between the main soil constituents and the total arsenic concentration (AsT) indicated that there was a significant correlation only with the total iron (FeT) concentration (Eq. 1), which indicates that As is likely to be absorbed as anionic forms by iron oxides precipitated in the soil (García et al., 2009).

$$
\text { AsT }=2 \cdot 10^{-5} \mathrm{FeT}^{4.009} \quad\left(\mathrm{r}^{2}=0.983\right)
$$

The mineralogical study of the most polluted soils in the affected area (García et al., 2009; Martín et al., 2008), indicated that the arsenic retention in these media should be related to the neoformation of iron hydroxysulfate minerals (jarosite $\left[\mathrm{KFe}_{3} \mathrm{SO}_{4}(\mathrm{OH})_{6}\right]$; schwertmannite $\left.\left[\mathrm{Fe}_{8} \mathrm{O}_{8}(\mathrm{OH})_{6} \mathrm{SO}_{4}\right]\right)$ and ferrihydrite $\left.\left[5 \mathrm{Fe}_{2} \mathrm{O}_{3} \cdot 9 \mathrm{H}_{2} \mathrm{O}\right]\right)$, suggesting that the removal of As through co-precipitation and adsorption reactions is probably the dominant solid-phase control on the mobility of arsenic (Bigham et al., 1996; Dold, 2003; Sánchez España et al., 2005). In this way, the retention of As in these soils would be related to the precipitation of relatively stable forms 
of ferrihydrite and schwertmannite; this process is related to the reduction of soluble As concentrations in soils (Carlson et al., 2002; Courtin-Nomade et al., 2003).

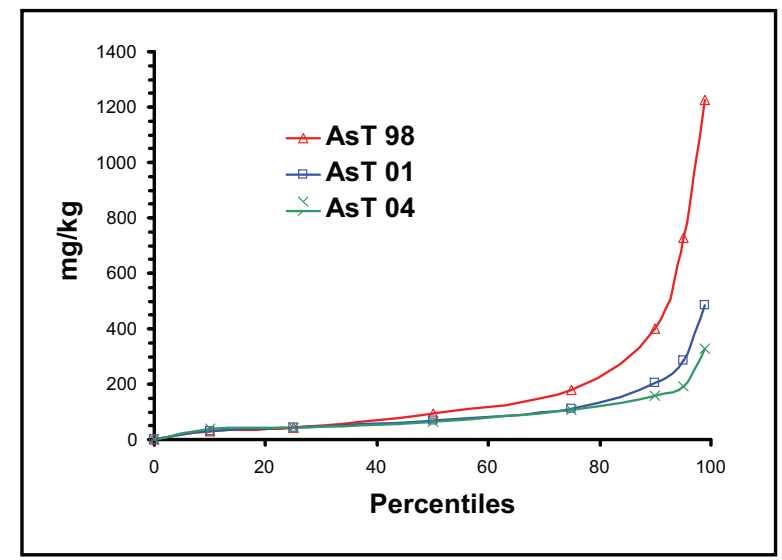

Fig. 2. Total arsenic concentrations (AsT) in the affected soils $(0-10 \mathrm{~cm})$ in 1998, 2001, and 2004

\subsection{Mobility, bioavailability, and toxicity of arsenic in soil (evolution during 6 years)}

In this type of pollution, toxicity and metal uptake are more accurately related to soluble and bioavalilable fractions than total metal concentrations in soil (Kumpiene et al. 2008). These forms are more related to the potential environmental risk of the pollution because they indicate the ability of the pollutant to be dispersed by the environment or transferred to organisms (animals and plants) living in the affected ecosystem. In this way, the soil is usually considered as a key factor to control and avoid environmental contamination. Soil acts as a buffering medium that receives contaminants and in many cases, due to the interaction with the soil constituents and properties, the pollution is minimized and the dispersion of the contaminants to other more sensitive media such as water or organisms is strongly reduced.

The easiest form of a pollutant to mobilize in the soil is the soluble-in-water form. Arsenic is a highly toxic element and therefore the toxic levels in soil solution are reported at very low concentrations (0.04 mg As $\mathrm{kg}^{-1}$ soil; Bohn et al., 1985). The soluble-in-water forms were extracted just after the first clean-up actions (at the end of 1998), three (in 2001) and six years (in 2004) later (Figure 3). In this period, the solubility of the As forms strongly reduced in the polluted soils. After the end of the first remediation actions in 1998, high amounts of As remained soluble in the affected soils, with more than $50 \%$ of the soils exceeding the toxic level. Three years later, there was a decline in the As solubility, although $19 \%$ of affected soils surpassed the toxic level, with differences depending on the soil properties $(10 \%$ in the carbonate sector and $25 \%$ in the non-carbonate sector). Six years after the accident, there was a sharp reduction in the soluble-in-water forms of As, only the $5 \%$ of the affected soils exceeding the toxic level, with no significant differences being found between the carbonate and the no-carbonate sector.

The forms extracted with EDTA are considered to be bioavailable by many authors because they are related to the carbonates, inorganic precipitates, amorphous oxides or organic ligands that can be uptaken by most plants (Beckett, 1989; Quevauviller et al., 1998; Rendell et al., 1980; Sposito et al., 1982). In this way, arsenic extracted by EDTA significantly differed over time (Table 1$)$. 

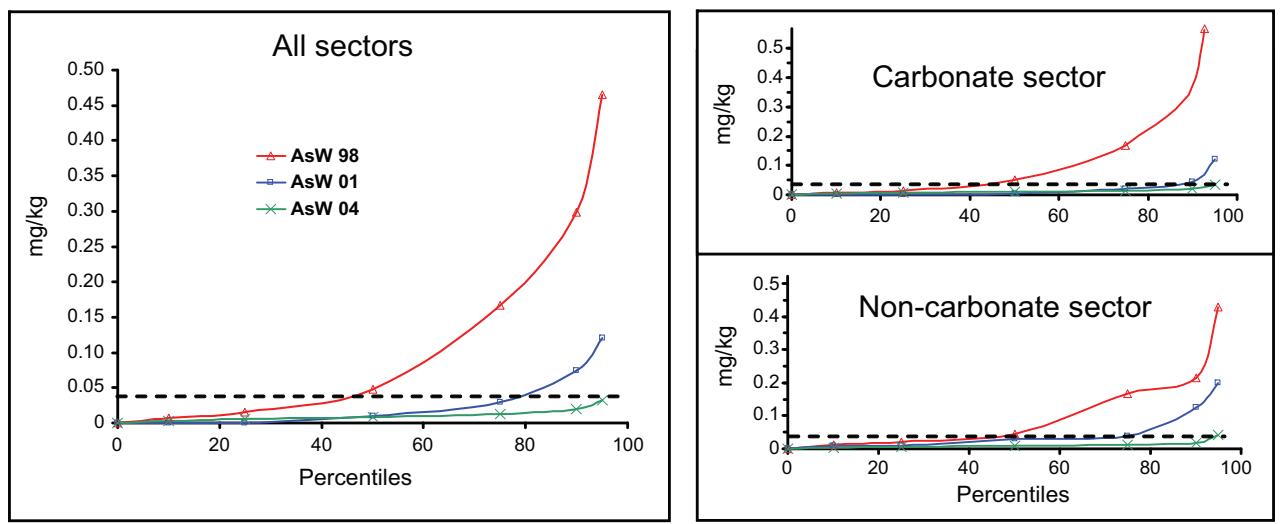

Fig. 3. Soluble-in-water arsenic concentrations (AsW) in all the affected soils and in the different sectors (carbonate and non-carbonate) in 1998, 2001, and 2004 (doted line: toxic level $0.04 \mathrm{mg} \mathrm{kg}^{-1}$; Bohn et al., 1985)

\begin{tabular}{|l|c|c|c|}
\hline & 1998 & 2001 & 2004 \\
\hline All soils & 58 & 12 & $\mathrm{bl}$ \\
\hline Non-carbonate sector & 69 & 25 & $\mathrm{bl}$ \\
\hline Carbonate sector & 50 & 2 & $\mathrm{bl}$ \\
\hline
\end{tabular}

Table 1. Percentage of soils exceeding the level of $2 \mathrm{mg} \mathrm{kg}^{-1}$ of As extracted with EDTA in all the affected soils and in the different sectors (carbonate and non-carbonate) in 1998, 2001, and 2004 (bl: below level)

After the end of the first remediation actions in 1998, high amounts of As remained bioavailabe in the affected soils of all sectors, with around $58 \%$ of the soils exceeding the level of $2 \mathrm{mg} \mathrm{kg}^{-1}$. Three years later, there was a reduction in the solubility of As and only $12 \%$ of soils had bioavailable concentrations in As above the reference level, although $25 \%$ of affected soils were located in the non-carbonate sector and only $2 \%$ in the carbonate sector. Six years after the accident, there was a notable reduction in the bioavailable forms of As,

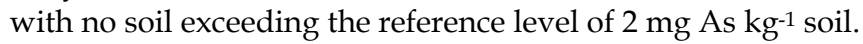

Bioassays were made to assess the toxicity of the affected soils 6 years after the accident. The toxicity was estimated from the soluble-in-water fraction using two types of bioassays: i) seed germination test (US EPA, 1996) with lettuce (Lactuca sativa L.); and ii) bioluminescent text (AZUR, 1998) with bacteria (Vibrio fischeri). These tests were applied because the toxicity related to the soluble-in-water fractions of contaminants reflects the behaviour of the most mobile fraction of pollutants and are strongly related to the high risk of dispersion, solubilization, and bioavailability of contaminants in the environment. Both assays used distilled water as a control.

This study was made in six georreferenced soils included in a heavily contaminated sector in 1998 (CS 98). The same study was repeated in the same six soils after the end of the remediation actions in 2004 (RS 04); six reference soils adjacent to the area but not affected by the spill were selected as uncontaminated soils (UCS). In all water extracts, $\mathrm{pH}$, electric conductivity and the soluble concentration of arsenic and other elements were determined. 
The results of the response of the bioluminescent bacteria after $15 \mathrm{~min}$ (I15) and the root elongation of lettuce seeds (RE) are presented in Table 2.

\begin{tabular}{|l|c|c|c|c|c|c|c|c|}
\hline & $\mathrm{pH}$ & $\begin{array}{c}\mathrm{EC} \\
\left(\mathrm{dS} \mathrm{m}^{-1}\right)\end{array}$ & $\begin{array}{c}\mathrm{CuW} \\
\left(\mathrm{mg} \mathrm{l}^{-1}\right)\end{array}$ & $\begin{array}{c}\mathrm{ZnW} \\
\left(\mathrm{mg} \mathrm{l}^{-1}\right)\end{array}$ & $\begin{array}{c}\mathrm{AsW} \\
\left(\mathrm{mg} \mathrm{l}^{-1}\right)\end{array}$ & $\begin{array}{c}\mathrm{PbW} \\
\left(\mathrm{mg} \mathrm{l}^{-1}\right)\end{array}$ & I15 & RE \\
\hline UCS & 7.62 & 0.56 & 0.02 & 0.02 & 0.01 & 0.01 & $(+) 30.5$ & $(+) 5.6$ \\
\hline CS 98 & 3.67 & 2.78 & 135.30 & 632.09 & 0.18 & 0.31 & $(-) 73.9$ & $(-) 66.8$ \\
\hline RS 04 & 7.05 & 2.16 & 0.67 & 10.25 & 0.01 & 0.92 & $(+) 5.1$ & $(+) 3.2$ \\
\hline
\end{tabular}

Table 2. Main properties of the water extracts [pH, electrical conductivity (EC) and solublein-water concentrations of pollutants] used in the bioassays with bioluminescent bacteria after 15 minutes (I15) and root elongation of lettuce seeds (RE)

The results indicate that the contaminated soils (CS 98) strongly inhibited bioluminescent bacteria ( $74 \%$ in relation to the control) and heavily reduced of the root elongation in lettuce (67\% in relation to the control). The most significant variables related to the toxicity were $\mathrm{pH}$, and the soluble concentrations in $\mathrm{Cu}$ and $\mathrm{Zn}$. Therefore, in this type of multi-elemental pollution, the As concentration in the water extract was not the main element related to the toxic response in both bioassays. The comparison of these results with those registered six years later in the same area after the end of the remediation actions (RS 04) indicated a sharp decline in the soluble concentrations of the pollutants, and a positive response in both bioassays. This indicates that no toxicity occurred in the selected soils after remediation and that the organisms in contact with the soil solution increased in luminescence or in root elongation compared to the control (hormesis). This positive response was also found in the uncontaminated soils of the area (UCS), indicating that the remediation measurements successfully lowered potential toxicity related to the soluble fraction in the polluted soils.

\subsection{Evolution of arsenic pollution twelve years after the accident}

Due to the remediation actions, some of the soil properties changed significantly from 2004 to 2010 (twelve years after the accident). The influence of the liming applied over the soils to avoid the acidification caused by the sulphide oxidation and to promote the precipitation of the pollutants raised the $\mathrm{pH}$ over time (Figure 4). In the non-carbonate sector (NCS) the rise over time was notable $(\mathrm{p}<0.001)$, with mean values of 5.75 in 2004, rising to 7.63 in 2010. In the carbonate sector (CS), the rise was less remarkable but also significant ( $p=0.004)$, ranging from mean values of 7.64 in 2004 to 8.25 in 2010. The differences in $\mathrm{pH}$ between sectors decreased over time but remained significantly different in all years. The soil organic carbon (OC) also showed a sharp increase during the study period, and the differences between sectors were significantly different in 2010 (Figure 4), due to the addition of organic amendments to help stabilize the soils and regenerate the vegetation, being this recovery more rapid in the carbonate sector. The soil OC content in 2004 in the NCS was close to 1\%, increasing significantly ( $\mathrm{p}=0.03$ ) to $1.3 \%$ in the last years sampled; meanwhile this increment was higher and statistically significant $(p<0.001)$ in the CS, where the OC reached mean values of close to $1.7 \%$.

After the potential contamination and the mobility of pollutants in the environment were minimized, a protected landscape configuration was established by the regional government of Andalusia (Spain), called the "Green Corridor of the Guadiamar River" (CMA, 2003). The use of all the agricultural soils within the affected area was prohibited to avoid the potential 
risk of high levels of total concentration in arsenic and other heavy metals in soils. Therefore, the remediation measurements during the study period 2004 - 2010 were focused on stabilizing the vegetation and protecting the area, causing the total concentration of arsenic to remain constant in the affected soils.
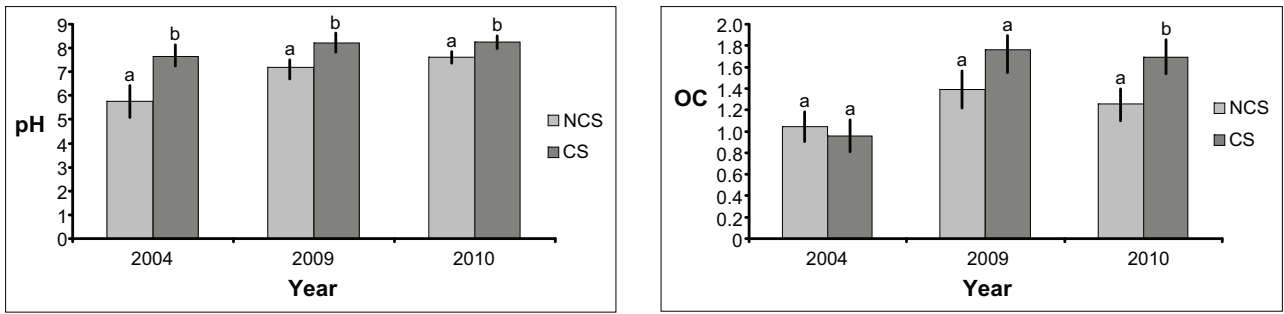

Fig. 4. Time course of $\mathrm{pH}$ and soil organic carbon (OC) in the non-carbonate sector (NCS) and carbonate sector (CS) in 2004, 2009, and 2010 (different letters indicate significant differences between sectors according Tukey test $\mathrm{p}<0.05)$

To study the medium-term development of the pollution, we repeated the same systematic sampling of the affected area in 2009 and 2010, eleven and twelve years, respectively, after the accident. The total As concentration in the affected soils, had not significantly changed over time. Six years after the spill (in 2004), the soil exceeding the intervention level of 100 mg As kg-1 soil was around $30 \%$ (40\% of the non-carbonate soils and $25 \%$ of the carbonate soils), and the percentage of soils exceeding this value in 2009 and 2010 remained approximately the same (Figure 5), with a similar ratio between the carbonate and noncarbonate sectors.

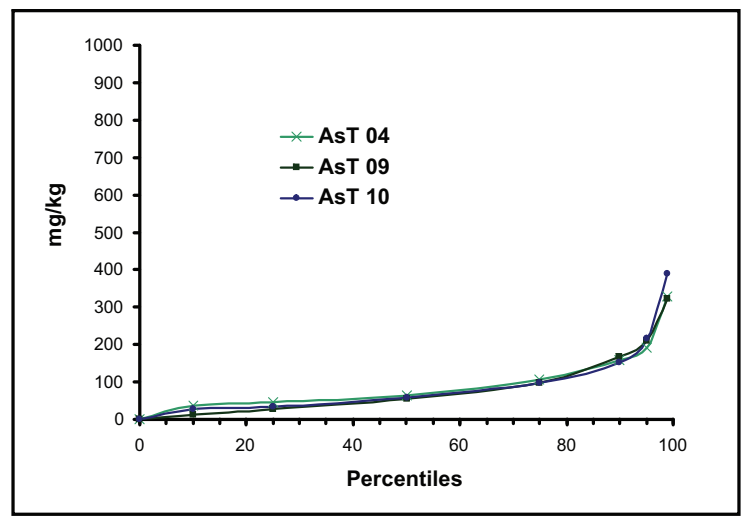

Fig. 5. Total arsenic concentrations (AsT) in the affected soils in 2004, 2009, and 2010

The arsenic mobility over time was also studied in 2009 and 2010 after analysing the solublein-water and the EDTA extracted forms. In relation to the previous sampling (in 2004) there was a sharp increase in the solubility of arsenic forms in remediated soils (Figure 6).

This increase occurred both in the non-carbonate as well as in the carbonate sector, indicating that the solubility of arsenic in soils has changed independently of the soil type. In relation to the EDTA extracted forms, considered to be bioavailable, the increase was also pronounced throughout the affected area. The concentration of As extracted with EDTA had 
a mean value of 0.49 and $0.41 \mathrm{mg} \mathrm{kg}^{-1}$ in 2004 in the non-carbonate and carbonate sectors, respectively. Six years later (in 2010) these concentration increased to 0.97 and $0.58 \mathrm{mg} \mathrm{kg}-1$ in both sectors, respectively.
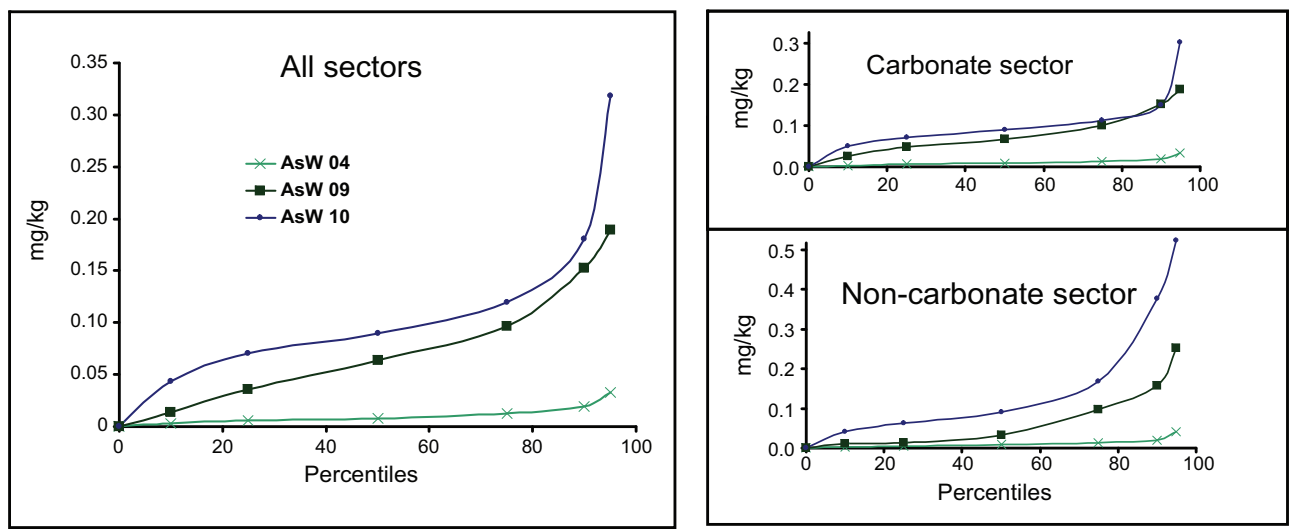

Fig. 6. Soluble-in-water arsenic concentrations (AsW) in all the affected soils and in the different sectors (carbonate and non-carbonate) in 2004, 2009, and 2010

The reduction of soluble As concentrations in these soils has been related, in the previous section, to As retention by iron oxi-hydroxides precipitated in the soils mainly as low crystallization forms (amorphous). In any case, some authors have described such adsorption as a reversible process (Carbonell et al., 1996). A correlation analysis was made between the mobile fractions of As and the main soil properties and constituents between the period 2004 to 2010 . This analysis gave a significant $(\mathrm{p}<0.001)$ and negative correlation between the soluble-in-water As forms (AsW) and the amorphous iron oxides (Feo) in soil, indicating that the reduction of these amorphous phases should be related to the increase in the arsenic concentration in the soil solution.

The quantification of the reduction in the amorphous iron oxides in the soil is not enough to explain the strong increase in the solubility of arsenic in the affected area, so we studied the main constituents that may influence As mobilization in soils. According to the different soil types described in Section 2, we made a correlation analysis between the mean values of the main soil properties and the arsenic forms; the main coefficients are presented in Table 3. Significant correlations were found between the soluble-in-water arsenic (AsW) with the $\mathrm{pH}$ and the organic carbon (OC) of the soil; also, As extracted with EDTA (AsE) significantly correlated with organic carbon. However, we found no correlation between the mobile As forms and the total concentration of As in the soil (AsT), indicating that after the remediation measurements the initial contamination has little influence on the As mobility in soils.

According to these results, a rise in $\mathrm{pH}$ can intensify the As concentration in the solution. Arsenic in soils has a high affinity for oxidic surfaces, and the reactivity of the oxides varies considerably with the $\mathrm{pH}$, the charge density, and the composition of the soil solution. Pierce and Moore (1980) demonstrated the specificity of the surface of iron hydroxides and the influence of $\mathrm{pH}$ in the As adsorption. In this way, significant desorption of As is observed with the rise of $\mathrm{pH}$; in this case, the rise in $\mathrm{pH}$ is related to the decrease of the positive surface charge of the iron oxides, which facilitates the desorption of arsenate (Ghosh et al., 2006; Klitzke \& Lang, 2009; Masscheleyn et al., 1991). 


\begin{tabular}{|l|c|c|c|c|}
\hline & AsW & AsE & AsT & $\mathrm{pH}$ \\
\hline AsE & $0.535\left(^{*}\right)$ & & & \\
\hline AsT & -0.188 & 0.082 & & \\
\hline $\mathrm{pH}$ & $0.639\left(^{(*)}\right.$ & 0.346 & $-0.634\left(^{* *}\right)$ & \\
\hline $\mathrm{CO}$ & $0.704\left(^{(*}\right)$ & $0.531\left(^{*}\right)$ & -0.384 & $0.691\left(^{* *}\right)$ \\
\hline
\end{tabular}

Table 3. Correlation matrix between the soluble-in-water (AsW), EDTA extracted (AsE), total arsenic (AsT) forms, $\mathrm{pH}$, and organic carbon (OC), in the different soil types in the period $\left.2004-2010\left(\mathrm{p}<0.05=\left(^{*}\right) ; \mathrm{p}<0.01={ }^{* *}\right)\right)$

Another key factor influencing As mobility in soils over time is the total soil organic carbon (OC). According to our data, a significant and positive correlation was found between the $\mathrm{AsE}$ and AsW with the total soil organic carbon (Table 3). The regression plot between the AsW and the OC is presented in the Figure 7 by a potential equation.

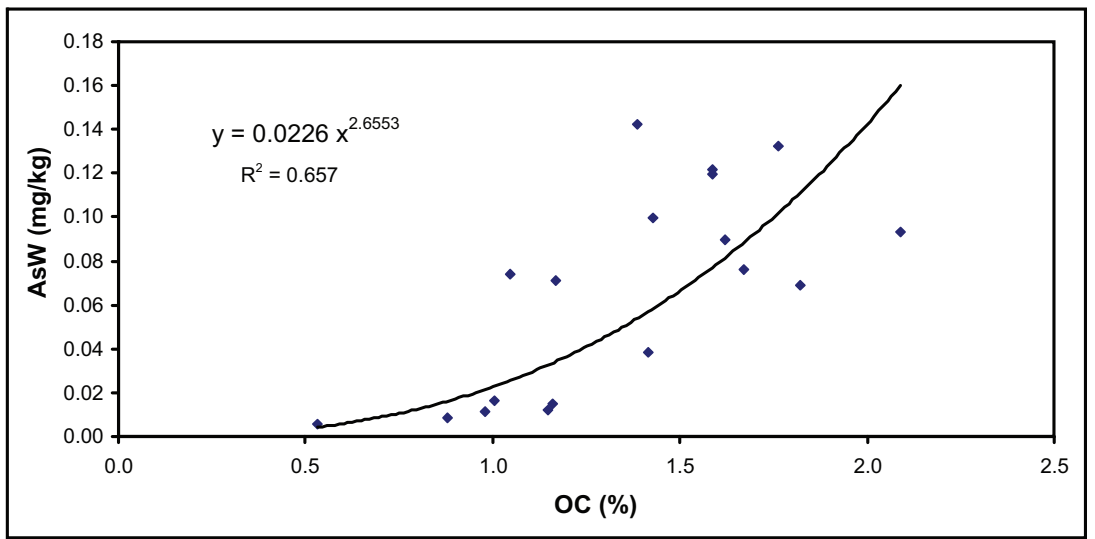

Fig. 7. Regression plot between soluble-in-water arsenic concentrations (AsW) and total soil organic carbon (OC) in all the different soil types between the period $2004-2010$

The presence of organic matter has been studied as a key factor in the desorption of As from iron oxides. In this sense, Redman et al. (2002) reported that the interaction between natural organic matter and hematite diminished the sorption of arsenate, promoting its mobility, while other authors have observed that dissolved organic matter can mobilize As from iron oxides, augmenting the concentration of this element in the solution (Bauer \& Blodau, 2006; Dobran \& Zagury, 2006; Mladenov et al., 2010). Therefore, the competing effect of organic matter with arsenate for surface sites should also be related to the mobilization of As retained in soils after the remediation actions.

\section{Conclusion}

Twelve years after the Aznalcóllar pyrite tailing spill, and after the end of all remediation actions made in the affected area, we detected a notable increase in the soluble-in-water and bioavailable arsenic forms previously retained by the amorphous iron oxides of the soils. In the affected soils, two main parameters seems to be related to the increase of As solubility 
over time, soil $\mathrm{pH}$ and total soil organic carbon. The rise in $\mathrm{pH}$ values under alkaline conditions caused by the liming applications, can be related to the decrease of the positive surface charge of the iron oxides which can trigger the desorption of the retained arsenate. Otherwise, the increase in soil organic matter content related to the revegetation of the soils can be related to the greater mobility of the arsenic in soils due to the competing effect for the surface sites. Monitoring and assessment of soils polluted by arsenic and remediated with amendment applications (mainly liming and organic matter) are necessary over the short to medium terms in order to control the desorption or mobilization of arsenic forms over time and to avoid the environmental risk related to the potential toxicity of the soil solutions.

\section{Acknowledgment}

This study has been made possible by the research project RNM-3315 of the Regional Environmental Department of the Andalusian Government, and by the research project CGL2010-19902 of the Science and Innovation Ministry of Spain. Also thanks goes to Mr. David Nesbitt for correcting the English of the manuscript.

\section{References}

Aguilar, J.; Bellver, R.; Dorronsoro, C.; Fernández, E.; Fernández, J.; García I.; Martín, F.; Ortiz, I. \& Simón, M. (2003). Contaminación de suelos por el vertido tóxico de Aznalcóllar. Junta de Andalucía, Consejería de Medio Ambiente, Sevilla, Spain.

Aguilar, J.; Dorronsoro, C.; Fernández, E.; Fernández, J.; García, I.; Martín, F.; Sierra, M. \& Simón, M. (2007a). Arsenic contamination in soils affected by a pyrite-mine spill (Aznalcóllar, SW Spain). Water, Air, and Soil Pollution, Vol.180, pp. 271-281.

Aguilar, J.; Dorronsoro, C.; Fernández, E.; Fernández, J.; García, I.; Martín, F.; Sierra, M. \& Simón, M. (2007b). Remediation of As-contaminated soils in the Guadiamar river basin (SW, Spain). Water, Air, and Soil Pollution, Vol.180, pp. 109-118.

Aguilar, J.; Dorronsoro, C.; Galán, E. \& Gómez, J.L. (1999). Criterios y estándares para declarar un suelo como contaminado en Andalucía, In: Investigación y Desarrollo Medioambiental en Andalucía, Univ. Sevilla, (Ed.), 45-59, Sevilla, España.

AZUR Environmental. 1998. The Microtox ${ }^{\circledR}$ Acute Basic, DIN, ISO and Wet Test Procedure. Carlsbad, Calif, USA.

Bascomb, C.L. (1961). A calcimeter for routine use on soil samples. Chem. Ind., Vol.45, pp. 1826-1827.

Bauer, M. \& Blodau, C. (2006). Mobilization of arsenic by dissolved organic matter from iron oxides, soils and sediments. The Science of the Total Enviromment, Vol.354, pp. 179190.

Bigham, J.M.; Schwertmann, U.; Traina, S.J.; Winland, R.L. \& Wolf, M. (1996). Schwertmannite and the chemical modelling of iron in acid sulphate waters. Geochim. Cosmochim. Ac., Vol.60, No.12, pp. 2111-2121.

Bohn, H.L.; McNeal. B.L. \& O’Connor, G.A. (1985). Soil Chemistry. Wiley Interscience, New York, USA.

Carbonell, A.; Burló, F. \& Mataix, J. (1996). Kinetics of arsenite desorption in Spanish soils. Communications in Soil Science and Plant Analysis, Vol.27, pp. 3101-3117. 
Carlson, L.; Bigham, J.M.; Schwertmann, U.; Kyek, A. \& Wagner, F. (2002). Scavenging of As from acid mine drainage by schwertmannite and ferrihydrite: A comparison with synthetic analogues. Environ. Sci. Technol., Vol.36, pp. 1712-1719.

Clemente, R.; Almela, C. \& Bernal, M.P. (2006). A remediation strategy based on active phytoremediation followed by natural attenuation in a soil contaminated by pyrite waste. Water, Air, and Soil Pollution, Vol.177, pp. 349-365.

Clemente, R.; Walker, D.J. \& Bernal, M.P. (2005). Uptake of heavy metals and As by Brassica juncea grown in a contaminated soil in Aznalcóllar (Spain): The effect of soil amendments. Environmental Pollution, Vol.138, No.1, pp. 46-58.

CMA. (2003) Decreto 112/2003 de 22 de Abril to declare the protected landscape of the Green Corridor of Guadiamar. Consejería de Medio Ambiente, Junta de Andalucía, Spain.

Courtin-Nomade, A.; Bril, H.; Neel, C. \& Lenain, J. (2003). Arsenic in iron cements developed within tailings of a former metalliferous mine-Enguiales, Aveyron, France. Appl. Geochem., Vol.18, pp, 395-408.

Dobran, S. \& Zagury, G.J. (2006). Arsenic speciation and mobilization in CCA- contaminated soils: Influence of organic matter content. The Science of the Total Environment, Vol.364, pp. 239-250.

Dold, B. (2003). Dissolution kinetics of schwertmannite and ferrihydrite in oxidized mine samples and their detection by differential X-ray diffraction (DXRD). Appl. Geochem., Vol.18, pp. 1531-1540.

Dorronsoro, C.; Martín, F.; Ortiz, I.; García, I.; Simón, M.; Fernández, E.; Fernández, J. \& Aguilar, J. (2002). Migration of trace elements from pyrite tailings in carbonate soils. J. Environ. Qual., Vol.31, pp. 829-835.

Dudas, M. J. (1987). Accumulation of native arsenic in acid sulphate soils in Alberta. Canadian Journal of Soil Science, Vol.67, pp. 317-321.

Foster, A. L. (2003). Spectroscopic investigation of arsenic species in solid phases, In: Arsenic in ground water: geochemistry and occurrence, A. H. Welch \& K. G. Stollenwerk (Eds.), 27-65. Boston, USA.

García, I.; Diez, M.; Martín, F.; Simón, M. \& Dorronsoro, C. (2009). Mobility of arsenic and heavy metals in a sandy-loam textured and carbonated soil. Pedosphere, Vol.19, No.2, pp. 166-175.

Ghosh, A.; Sáez, A.E. \& Ela, W. (2006). Effect of pH, competitive anions and NOM on the leaching of arsenic from solid residuals. Science of the Total Environment, Vol.363, pp. 46- 59.

Hiltbold, A.; Hajek, B.F. \& Buchanan, G.A. (1974). Distribution of arsenic in soil profiles after leaching. Soil Science Society of America Proceedings, Vol.38, pp. 647-652.

Jiang, W.; Zhang, S.; Shan, X.; Feng, M.; Zhu, Y. \& McLaren, R. G. (2005). Adsorption of arsenate on soils. Part 2: Modeling the relationship between adsorption capacity and soil physiochemical properties using 16 Chinese soils. Environmental Pollution, Vol.138, pp. 285-289.

Kabata-Pendias, A. \& Pendias, H. (2001). Trace elements in soils and plants (3rd ed.), CRC Press, Boca Raton, Florida, USA.

Klitzke, S. \& Lang, F. (2009). Mobilization of Soluble and Dispersible Lead, Arsenic, and Antimony in a Polluted, Organic-rich Soil - Eff ects of $\mathrm{pH}$ Increase and Counterion Valency. J. Environ. Qual, Vol.38, pp. 933-939. 
Kumpiene, J.; Lagerkvist, A. \& Maurice, C. (2008). Stabilization of As, Cr, Cu, Pb and Zn in soils using amendments - A review. Waste Management, Vol.28, pp. 215-225.

López-Pamo, E.; Barettino, D.; Antón-Pacheco, C.; Ortiz, G.; Arránz, J.C.; Gumiel, J.C.; Martínez-Pledel, B.; Aparicio, M. \& Montouto, O. (1999). The extent of the Aznalcóllar pyritic sludge spill and its effects on soils. The Science of the Total Environment, Vol.242, pp. 57-88.

Loveland, P.J. \& Whalley, W.R. (1991). Particle size analysis. In: Soil analysis: Physical methods, K.A. Smith \& C.E. Mullis (Eds.), Marcel Dekker, 271-328, New York, USA.

Madejón, P.; Murillo, J.M.; Marañón, T.; Cabrera, F. \& Soriano, M.A. (2003). Trace element and nutrient accumulation in sunflower plants two years after the Aznalcóllar mine spill. The Science of the Total Environment, Vol.307, pp. 239-257.

Marin, A.; Masscheleyn, P.J. \& Patrick, W.H. (1993). Soil redox-pH stability of arsenic speciation. Environmental Science \& Technology, Vol.33, pp. 773-781.

Martín, F. (2002). Pollution of soils by the spill of a pyrite mine (Aznalcóllar, Spain), PhD Thesis, University of Granada, Spain.

Martín, F.; García, I.; Diez, M.; Sierra, M.; Simón, M. \& Dorronsoro, C. (2008). Soil alteration by continued oxidation of pyrite tailings. Applied Geochemistry, Vol.23, pp. 11521165.

Masscheleyn, P.H.; Delaune, R.D. \& Patrick, W.H. (1991). Effect of redox potential and pH on arsenic speciation and solubility in a contaminated soil. Environmetal Science $\mathcal{E}$ Technology, Vol.25, pp. 1414-1419.

Mladenov, N.; Zheng, Y.; Miller, M.P.; Nemergut, D.R.; Legg, T.; Simone, B.; Hageman, C.; Rahman, M.M.; Ahmed, K.M. \& Mcknight, D.M. (2010). Dissolved organic matter sources and consequences for iron and arsenic mobilization in Bangladesh aquifers. Environmental Science and Technology, Vol.44, No.1, pp. 123-128.

Mudarra, J. L. (1988). Study of soils in the Aljarafe region. Regional Education and Science Department of the Andalusia Government, Seville, Spain.

N.R.C.C. (1978). Effects of arsenic in the Canadian environment. National Research Council of Canada, no. 15391, Ottawa, Canada.

Nordstrom, D.K. (1982). Aqueous pyrite oxidation and the consequent formation of secondary iron minerals. In: Acid sulfate weathering, J. A. Kitrick, D. S. Fanning, \& L. R. Hossner (Eds.), Soil Science Society of America, 37-56, Madison, USA.

O'Neill, P. (1995). Arsenic. In: Heavy metals in soils (2nd ed.) B.J. Alloway (Ed.), 105-121. Glasgow, UK.

Peñalosa, J.M.; Carpena, R.O.; Vázquez, S.; Agha, R.; Granado, A.; Sarro, M.J. \& Esteban, E. (2007). Chelate-assisted phytoextraction of heavy metals in a soil contaminated with a pyritic sludge. The Science of the Total Environment, Vol.378, pp. 199-204.

Pérez-de-Mora, A.; Madejón, E.; Burgos, P. \& Cabrera, F. (2006). Trace elements availability and plant growth in a mine-spill-contaminated soil under assisted natural remediation I. Soils. The Science of the Total Environment, Vol.363, pp. 28-37.

Pierce, N.L. \& Moore, C.B. (1980). Adsorption of arsenite and arsenate on amorphous iron hydroxide from dilute aqueous solutions. Environmental Science $\mathcal{E}$ Technology, Vol.14, pp. 214-216.

Quevauviller, Ph.; Lachica, M.; Barahona, E.; Gómez, A.; Rauret, G.; Ure, A. \& Muntau, H. (1998). Certified reference material for the quality control of EDTA and DTPA extractable trace metal contents in calcareous soils (CRM 6000). Presenius J. Anal. Chem., Vol.360, pp. 505-511. 
Redman, A.D.; Macalady, D.L. \& Ahmann, D. (2002). Natural organic matter affects arsenic speciation and sorption onto hematite. Environmental Science E Technology, Vol.36, pp. 2889-2896.

Sánchez España, J.; López Pamo, E.; Santofimia, E.; Aduvire, O.; Reyes Andrés, J. \& Barettino, D. (2005). Acid mine drainage in the Iberian Pyrite Belt (Odiel river watershed, Huelva, SW Spain): Geochemistry, mineralogy and environmental implications. Appl. Geochem., Vol.20, pp 1320-1356.

Schwertmann, U. \& Taylor, R.M. (1977). Iron oxides. In: Minerals in soil environments, J. B. Dixon \& S. B. Webb (Eds.), Soil Science Society of America, 148-180. Madison, USA.

Simón, M.; Díez, M.; García, I. \& Martín, F. (2009). Distribution of As and Zn in Soils Affected by the Spill of a Pyrite Mine and Effectiveness of the Remediation Measures. Water, Air, and Soil Pollution, Vol.198, pp. 77-85.

Simón, M.; Dorronsoro, C.; Ortiz, I.; Martín, F. \& Aguilar, J. (2002). Pollution of carbonate soils in a Mediterranean climate due to a mailing spill. Eur. J. Soil Sci., Vol.53, pp. 321-330.

Simón, M.; García, I.; Martín, F.; Díez, M.; del Moral, F. \& Sánchez, J.A. (2008). Remediation measures and displacement of pollutants in soils affected by the spill of a pyrite mine. The Science of the Total Environment, Vol.407, pp. 23-39.

Simón, M.; Martín, F.; García, I.; Dorronsoro, C. \& Aguilar, J. (2007). Steps in the Pollution of Soils after a Pyrite Mine Accident in a Mediterranean Environment, In: Environmental Pollution: New Research, Nova Publishers, (Ed.), 185-224, ISBN 160021-285-9, New York, USA.

Simón, M.; Martín, F.; Ortiz, I.; García, I.; Fernández, J.; Fernández, E.; Dorronsoro, C. \& Aguilar, J. (2001). Soil pollution by oxidation of tailings from toxic spill of a pyrite mine. The Science of the Total Environment, Vol.279, pp. 63-74.

Simón, M.; Ortiz, I.; García, I.; Fernández, E.; Fernández, J.; Dorronsoro, C. \& Aguilar, J. (1999). Pollution of soils by the toxic spill of a pyrite mine (Aznalcóllar, Spain). The Science of the Total Environment, Vol.242, pp. 105-115.

Simón, M.; Ortiz, I.; García, I.; Fernández, E.; Fernández, J.; Dorronsoro, C. \& Aguilar, J. (1998). El desastre Ecológico de Doñana. Edafología, Vol.5, pp. 153-161.

Smith, I. C.; Naidu, R. \& Alston, A. M. (1998). Arsenic in the soil environment. A review. Advances in Agronomy, Vol.64, pp. 150-195.

Soil Survey Staff. (1951). Soil survey manual. Handbook 18. USDA, Washington DC, USA.

Soil Survey Staff. (2003). Keys to soil taxonomy (9th ed.), Blacksburg, Virginia, USA.

Stumm, W. \& Morgan, J.J. (1981). Aquatic chemistry: An introduction emphasizing chemical equilibria in natural waters. John Wiley and Sons, New York, USA.

Sun, X. \& Doner, H. E. (1996). An investigation of arsenate and arsenite bonding structures on goethite by FTIR. Soil Science, Vol.161, pp. 865-872.

US EPA (US Environmental Protection Agency). 1996. Ecological effects test guidelines. Seed germination/root elongation toxicity test. OPPTS 850.4200.

Waychunas, G. A.; Rea, B. A.; Fuller, C. C. \& Davis, J.A. (1993).Surface chemistry of ferrihydrite: Part 1. EXAFS studies of the geometry of coprecipitated and absorbed arsenate. Geochimica et Cosmochimica Acta, Vol.57, pp. 2251-2269.

Young, R.N. \& Mulligan, C.N. (2004). Natural attenuation of contaminants in soils. CRC Press, Boca Raton, Florida, USA. 


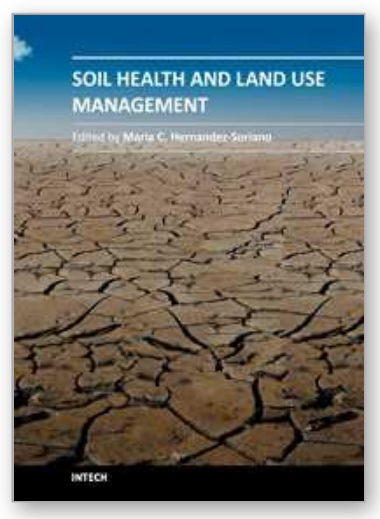

\author{
Soil Health and Land Use Management
}

Edited by Dr. Maria C. Hernandez Soriano

ISBN 978-953-307-614-0

Hard cover, 332 pages

Publisher InTech

Published online 25, January, 2012

Published in print edition January, 2012

Soils play multiple roles in the quality of life throughout the world, not only as the resource for food production, but also as the support for our structures, the environment, the medium for waste disposal, water, and the storage of nutrients. A healthy soil can sustain biological productivity, maintain environmental quality, and promote plant and animal health. Understanding the impact of land management practices on soil properties and processes can provide useful indicators of economic and environmental sustainability. The sixteen chapters of this book orchestrate a multidisciplinary composition of current trends in soil health. Soil Health and Land Use Management provides a broad vision of the fundamental importance of soil health. In addition, the development of feasible management and remediation strategies to preserve and ameliorate the fitness of soils are discussed in this book. Strategies to improve land management and relevant case studies are covered, as well as the importance of characterizing soil properties to develop management and remediation strategies. Moreover, the current management of several environmental scenarios of high concern is presented, while the final chapters propose new methodologies for soil pollution assessment.

\title{
How to reference
}

In order to correctly reference this scholarly work, feel free to copy and paste the following:

Francisco Martín, Mariano Simón, Elena Arco, Ana Romero and Carlos Dorronsoro (2012). Arsenic Behaviour in Polluted Soils After Remediation Activities, Soil Health and Land Use Management, Dr. Maria C. Hernandez Soriano (Ed.), ISBN: 978-953-307-614-0, InTech, Available from: http://www.intechopen.com/books/soilhealth-and-land-use-management/arsenic-behaviour-in-polluted-soils-after-remediation-activities

\section{INTECH}

open science | open minds

\section{InTech Europe}

University Campus STeP Ri

Slavka Krautzeka 83/A

51000 Rijeka, Croatia

Phone: +385 (51) 770447

Fax: +385 (51) 686166

www.intechopen.com

\section{InTech China}

Unit 405, Office Block, Hotel Equatorial Shanghai

No.65, Yan An Road (West), Shanghai, 200040, China 中国上海市延安西路65号上海国际贵都大饭店办公楼405单元

Phone: $+86-21-62489820$

Fax: +86-21-62489821 
(C) 2012 The Author(s). Licensee IntechOpen. This is an open access article distributed under the terms of the Creative Commons Attribution 3.0 License, which permits unrestricted use, distribution, and reproduction in any medium, provided the original work is properly cited. 